\title{
Igbo Language and Identity
}

\author{
Umo Uju Clara \\ University of Nigeria, Nsukka, Nigeria
}

\begin{abstract}
This paper sought to identify the position of Igbo language in relation to its identity both in Nigeria and world wide. Specifically, it expounded the problems hindering the study of Igbo language. A study of Igbo language and identity is pertinent because language and culture are attached to man's identity and human interaction. Unfortunately, most of the Igbos do not want to be identified with this language called Igbo. The paper reviewed available literature on Igbo language and highlighted some strategies for increasing the interest of people in learning Igbo language. It was discovered from the study that pedagogical problems, tone problems, orthography, and diacritic problems, are some of the issues that inhibit the repositioning of Igbo language as Igbo man's identity. In view of this, it was recommended among others that Igbo linguist should try and document all the slight phonological and word differences existing in the dialects and absorb them in central Igbo.
\end{abstract}

Keywords: identity, culture, language, dialectics, pedagogy, mother tongue, orthography, policy

\section{Introduction}

Language is a unifying factor, hence, it brings about national unity. More than mere communication, language is a powerful means of verbal transmission of ideas from the speaker to the receiver/public. It is an organized system, which means that its constituent elements are well-organised and well-integrated (Ohaegbu, 2010). He further noted that in our attempt to define language we refer to it as "heritage”. It is indeed a priceless and most enduring common heritage which members of any linguistic community derive from their common ancestors as indelible mark of their identity. Education is the power house to the development of any language; hence, any society that toys with the education of its citizenry will obviously experience snail speed development wise. One of the national educational goals, is that education shall continue to be highly rated in the national development plan, because education is the most important instrument of change. By implication, any fundamental change in the intellectual and social outlook of any society has to be preceded by an educational revolution, which in turn stabilizes the language of such society.

Any language is of great importance to man's life. Its significance can be looked at through its varied uses. Language is seen as a vehicle of communication, socialization, economic value, polishing tool, preservation of culture, building tool, vehicle for learning, excavating tool, personality development etc..

The standard of education in general and Igbo language in particular in our various schools in Nigeria has become a common issue of discussion among the public. This trend has invariably affected the Igbo man's identity. Igbo language is the language of the Igbos, therefore, it is the Igbo man's identity. It is believed that

Umo Uju Clara, professor, Department of Arts Education, University of Nigeria. 
speakers who embrace the identity of a particular community will engage in positive identity practices, while those who reject the identity will use negative identity practices to distant themselves from it (Bucholtz, 1999). Furthermore, Spolsky (1999) noted that conflict arises when the hearer has a different understanding of the speaker's identity than the one that the speaker desires.

This paper, therefore, exposed those variables which make it difficult for Igbo man to identify him/herself with the language and try to re-position the language to wear a new look as Igbo man's identity because of Nkiruka. These factors are discussed below: (1) poor method of teaching Igbo as a subject; (2) dialectical problems; (3) attitude problems; (4) nature of Igbo language; (5) inadequate instructional material; (6) tone problem; (7) orthography controversy; (8) governmental policy etc.; (9) popularity of English over Nigerian languages; (10) teacher's preparedness; (11) practical example of Nkiruka; and (12) full explanation of these highlights forms the study pattern of this presentation.

\section{Pedagogical Problems}

Pedagogy has to do with teaching. Teaching needs various methods to enable it achieve its objectives. Teaching methods vary as teachers vary. It depends on the orientation of the individual teacher and perhaps the location of the school (Okobiah, 1990). The method of teaching any subject directly affects the level of motivation of the students. Baldeh (1990) pointed out that every language teacher consciously or unconsciously employs a method peculiar either to enhance his teaching in order to impact on himself or to the society in which he finds himself. Some people believe that the method employed is the cause or failure in language learning. The present author observes that it is not in doubt that some teachers still teach Igbo language in English language inspite of the fact that they have been advised to use standard Igbo. This is why Ubahakwe (1977a) and Umo (2001) indicated that Igbo language teachers engage in an intricate psycholinguistics see-saw in preparing their lessons. An idea is conceived in Igbo, it is then coded in English in the class. The bewildered children begin from the opposite end of the see-saw. They learn a concept in English, decode it in Igbo and code it back into English in their role. Further contended that the psycho-linguistic see-saw is further worsened by the examination bodies. The WAEC (West Africa Examinations Council) in its question in Igbo coded the instructions in English for the Candidates to decode them into Igbo before answering the question. This typical situation was exemplified in November 1985, GCE (General Certificate Examination), Igbo, part III question 3, which stated: write two Igbo sentences to illustrate the use of "ka": (1) As an auxiliary verb; (2) As a verb; (3) To show time; and (4) As a subordinate construction.

These anomalies often forced the Igbo teachers to teach in English instead of in Igbo in Igbo lessons which also creates problems for Igbo students. Furthermore, Igbo language teachers appeared to neglect the use of different method in teaching the language. The method adopted is monotonous and dull. It is uncommon to see some students sleeping in the class, while the lesson is going on. Ubahakwe (1977b) observed that:

Young learners of 70's and much older learners before them chorus in loud unism the A B G B D E as the teachers (and later the pupils) in turn call out he letter displayed on the wall chart. The cacophony is reminiscent of the toad song in rainy season by the water side until the names of the letters are recited with ease. (p. 7)

Definitely, this type of method will automatically make an Igbo language student to loose hope and identity. Varied example is a useful tool a language teacher should adopts to make his teaching relevant and more 
meaningful. Umo (2001) developed a game package for teaching vowel harmony and word formation in Igbo which is a novelty that could bring back lost identity. A summary of this empirical study is presented as the way forward at the last lap of this study. No wonder Ohaegbu (2010) noted that lost of an individual's mother-tongue and cultures always lead to regrettable crisis of identity and alienation from one's natural human landscape. It creates destructive anguish in the psych of the victim. Lamenting on the loss of one's identity, a protagonist lamenting in adulthood over how he was pulled out of his natural ethno-linguistic community at a tender age when his mother tongue and culture had not yet taken roots in him and obliged to grow and mature in an alien language and culture that of France, his country's colonizer (Ohaegbu, 2010).

The young Senegalese ended up losing his identity and becoming what he himself acrimoniously termed "hybrid”. Being asked how it all happened, Diallo replied:

I don't know how too well. Perhaps it was with their alphabet with it, they struck the first hard blow at the country of the Diallobe. I remained for a long time under the spell of these signs and these sounds which constitute the structure and the music of their language. When I learnt to fit them together to form words, to fit the word together to give birth to speech, my happiness knew no further limit. (as cited in Ohaegbu, 2010, p. 159)

The statement above points to the fact that the young Diallo was naïve and his early happiness over his ability to speak the language until later in the novel when he lost his own language and identity, and latterly, he lamented over the "hybrid" which he had become. This means that language is synonymous with identity. By implication for an Igbo scholar to retain his/her identity, the Igbo language must be cherished, protected, and developed by people both in speech and written form.

\section{Dialectal Problems}

The Igbo language is spoken by some groups of people in the eastern part of Nigeria. It is spoken in Enugu, Ebonyi, Anambra, Imo, and Abia States of Nigeria. Other states where Igbo language is spoken include Delta and Rivers States. These states use language as a verbal means of communication. However, all speakers of a particular language do not use that language in a uniform way. This means that a language has what we can call speech varieties. That is a language has many varieties in spoken form which is recognized by users of different social communities. These variations are referred to as dialects. In other words, dialects refer to speech varieties within a particular language. Some people see dialect as separateness, backwardness and regional. But the most important thing is that it deviates from the standard Igbo in features such as phonology, syntax, and vocabulary. This is why Wikipedia Encyclopedia defines dialect as a variety of a language used by people from a particular geographical area. The number of speakers and the area itself can be of arbitrary size.

Dialect is a term used to describe features of grammar, vocabulary, and pronunciation of a language. The dialects of Igbo are quite many and are appreciated by their users as they serve them in their cultural, political, economic, and other social functions. However, these dialects are not accepted in literary use because of its multiplicity in the language. This is why Oluikpe (1979) sees a dialect as a sum total of the linguistic features which identify people from different parts of a language community. A language community can adopt a dialect which is distinct from the other dialects. This is true because language is said to be arbitrary in nature. However, there is a general impression of mutual intelligibility among speakers of different dialect, which means that speakers of one variety can understand speakers of another varieties and no one dialect can claim superiority over 
another. Instead, you may have what we call regional, sub-regional, social, or even religious varieties of the parent language (Oluikpe, 1979).

The "Standard Igbo" formed by SPILC (Society for Promotion of Igbo Language and Culture) in 1973, embraced more people and involved both the major and minor dialects in the formation of the standard dialect called "Standard Igbo". Although SPILC tried to set up a standard dialect, there is an indication that it is limited to the writing form of language which means that the problem still exists with the spoken form of the language. This invariably affects both the teaching and learning of Igbo language. Ikekeonwu (1986) carried out research studies on dialects and came up with five groups of dialects namely: (1) Niger Igbo; (2) Inland Igbo; (3) Northern or wawa Igbo; (4) Riverine Igbo; and (5) Inland East Igbo.

In another study carried out by Nwozuzu (2008), she observed that Igbo dialects should not exceed twenty in number. This gave rise to the development of artificial standard dialect at different times in the history of Igbo studies in an effort to develop Igbo language. To Nwozuzu, the 20 Igbo dialects should serve as an umbrella covering other minor dialects.

Oluikpe (1979) produced a book titled Transformation in Igbo Language based on Ngwa dialect. Ikekeonwu (1985) studied Onitsha and Enyimba dialects and they all came up with their differences. Ida ward (1936) also made her own contribution as a brain behind union Igbo. She later discontinued with the union Igbo where she intended writing all the dialects. This was because she found out that Igbo language is very difficult to study due to too many dialects. Oraka (1983) re-affirmed that "people must have lost interest in the study of Igbo language, just like Schon who on finding out that there were hundreds of Igbo dialects became, disgusted and gave up the study of Igbo for twenty years” (p. 64).

This multiplicity of dialects implies that even within a particular language, there exists many dialects which pose a great problem for the teachers. This is because no teacher can learn all the dialects and be able to teach in any locality. The Igbo language, for instance, has many dialects. Therefore, the issue of a child having a home dialect distinct from one in which he is taught at school poses an obstacle to his learning the standard language. The dialectical problems of the teachers are even more compounded by the grouping of pupils from different dialectical region into a class (Umo, 1996). The heterogeneity of the class pupils' dialect makes it absolutely impossible for the teacher's own dialect to suit all the members of the class. This is why Emenanjo (1978) claimed that Igbo is a difficult language, because it is a tone language and exposes itself to various to dialects.

Furthermore, WAEC chief examiner's report (1972) pointed out two twin issues of dialect and orthography and stated that from the candidates' script, one could discover that the central dialect and approved new orthography have not yet been universally understood in certain speaking area of Nigeria. Still on the problems of dialects, the WAEC chief examiner's report (1993) pointed out that some candidates were unable to express themselves in a standard Igbo and this was a continuous mixture of the English word. All these problems as observed by Chief examiner buttress the point that dialect problems affect effectively teaching and learning of Igbo language.

Another area of teacher's problem is the vocabulary limitations of most Nigerian languages, like other African languages. As pointed out by Taiwo (1980), the Nigerian languages, like other African language, though in international settings, are deficient in expressing concepts, ideas, though, skills, and techniques which Western Education has introduced into modern Nigerian Education. No wonder Nwokedi (1984) observed that Igbo 
language does not have established writing, not to talk of meta language. This deficiency limits the use of any one Nigerian language as medium of instruction and as a means of communication in handling many more phenomena.

Table 1 shows three Igbo dialectical interpretations of some English concepts.

Table 1

Three Igbo Dialectical Interpretations of Some English Concepts

\begin{tabular}{|l|l|l|l|}
\hline Concept & Udi & Nsukkka & Onitsha \\
\hline Body & Ehu & Eshu & Aru \\
\hline Orange & Oloma & Orume & Oloma \\
\hline Hand & Eka & Eka & Aka \\
\hline Here & Nwanu & Nwabe & Ebea \\
\hline Now & Nnwo & Nwoshia & Kita \\
\hline Eye & Enya & Enya & Anya \\
\hline
\end{tabular}

The issue is that these dialects compete among themselves for official recognition. Based on this, many writers write Igbo language texts from various linguistic groups. This is why Emenanjo (1975) lamented that it is quite unbelievable that Igbo school of thoughts still can not arrive at a consensus on the issue of standard Igbo language despite the competitive situation in Nigeria.

Furthermore, many learners are so involved in their own dialect hat they find it very difficult to understand, teachers who are from other dialectical groups even when these teachers are using central dialect. The fear of one dialectical group dominating another is so great that no group would wish the teaching and learning or indigenous language to be outside their own. Using Nsukka dialect as an example, Ohi in Umo (2001) discovered the following: (1) The psychological structure of Nsukka main dialect is an obstacle on the learning of standard Igbo; (2) the morphological differences of Nsukka main dialect is also an obstacle to the study of standard Igbo; and (3) there are also differences in both lexical and syntactic items of Nsukka and that of standard Igbo.

These problems constitute serious setback to the teaching and learning of Igbo language in schools as well as problems to the growth and development of Igbo language in general. It, therefore, becomes important that these dialectical problems be identified and that solutions be found.

This paper, therefore, is advocating the following measures as a way forward: (1) Scholars of Igbo language should lay more emphasis on the study of dialects because it can be useful to the development of more and standard written language; (2) only qualified Igbo teachers should be employed to teach Igbo in schools; (3) teachers should not stick to only their indigenous dialects. They should have open mind so as to versatile with other dialects; (4) seminars and workshops should be organized for Igbo teachers with emphasis laid on the study of dialects; and (5) Igbo language specialists should be involved in Igbo text writing for schools.

\section{Attitude}

Attitude means predisposition to act or react. It has been observed that the attitude of the general public in Igbo speaking areas to Igbo language growth and development is quite low. At times, if you say that you are studying Igbo, you become object of ridicule and caricature. Parents are even worst in this reaction. In reaction to negative attitude of parents, Ogbalu (1975) warned "parents who forbid their children to speak Igbo and flood 
their house with ugly sound of Daddy and Mummy should stop doing so, for they are doing their children incalculable harm” (Okeke, 2001, p. 48). Writing on the interest of Igbo, elites Afigbo (1975) noted that the majority of educated Igbos are never interested in their language that most of them can not read or write in their dialect.

The Igbo man having been brought in the colonial system of education and life style has a great interest for foreign language. This reaction of Igbo man gradually spread to influence other aspects of Igbo language and culture. Most students do not have interest in Igbo language as a subject. They are even not allowed to speak Igbo in the class which boosts their poor attitude which the Igbo in general have towards the language. This is why Oraka (1983) complained that it is a matter of a great regret that teachers and Igbo nationals neglect their mother tongue in schools while they promote and encourage the study of foreign language. More even in UNN (University of Nigeria, Nsukka), which is in Igbo land offer course in foreign language to their students earlier than on Igbo which was lately introduce in 1977/1978 academic session. It was also in the same year that the Anambra State Government included Igbo as one of the subjects in the first school leaving certificates. Even the 1993, 1996, 1997 and 1998, WAEC chief examiner's report show that there was poor performance of candidates in Igbo.

The popularity of English over Nigerian language poses, perhaps, of the heaviest problem to the study of Igbo language. English happens to be an international language which accords social prestige and access to Western employment to those who use it fluently. There English has somewhat affected the psychological disposition of Nigeria who prefer proficiency in English language to that of Igbo language. This invariably affects the Igbo man's identify.

It is rare to see a group of Igbo elites discuss issues with Igbo as language of expression. Their preferred language is English. Unlike the Yoruba and Hausas who proudly discuss with their mother tongue. Where is the Igbo man's identify? The attitude of our high school and university students to Igbo is even worse than the educated elites. These our students whom the future of the nation belong to have no regard and have equally thrown away the use of the language in discussion. Ndi Igbo ebe ka anyi na-aga? (The Igbos where are we heading to?) When a Yoruba man speaks you easily identify him through the language. The Igbo linguist must sensitize our students on Igbo language. Ndi Igbo tetanus n'ura (The Igbos, wake up from slumber). Igbo language should be a part of general studies courses at tertiary level. Thank God, UNIZIK (Nnamdi Azikwe University, Awka) is already doing that, Subakwa Igbo. A man is known and identified with his language and this is why language is a cultural mark of man.

Olagoke (1979) noted that the educated and rich men send their children to private schools where English language is used exclusively for teaching. It is even on record that some parents and common people do not send their children to common school where mother tongue are partially used still have a craving for instruction done substantially in English. The teachers grapple with both language learning difficulty and the waning interest of the pupils, and lack of encouragement from the parents and the society at large. This total neglect of Igbo led to Nwadike's lamentation in his 2008 inaugural lecture that the greatest injustice that can be committed to a person is to deprive him of his language. By implication a man who is deprived of his language is automatically denied of his identity. For Igbo students, to make giant strides attitudinal change should be the first step of action. Every Igbo man/woman should identify with Igbo language no matter the person's area of specialization, because Ebe 
Onye $\mathrm{Bi} \mathrm{Ka} \mathrm{O}$ na-awachi (This is our language, we must speak it and reverence it), and this is why Nwadike (2008), a professor of Igbo language, gave these warnings: "Which French man was more French than Dr. Leopold Sedar Senghor of Senegal? But at the hour of determining who was who in cultural identity, the French denied and rejected him” (p. 45). Which English man was more English than Joseph Konrad (a polish) but when the English decided to determine who was English, Joseph Konrad was rejected along with his English novels. These warnings were given to those Igbos who prefer to speak foreign languages to their mother tongue. Be warned! Stop glorifying other language, come back to your own language.

Any group that has no regard for his language has automatically lost both his culture and identity. Igbo man, where is your identity? Juo onwe gi ajuju a (examine yourself).

\section{Inadequate Instructional Materials}

The dearth of text books written in Igbo language also make it difficult to cater for education in mother tongue, because both teachers and pupils need to read extensively books written in their native language if they must study them. The paucity of good text books written in the mother tongue could be the greatest problems facing the language teachers in the classroom. However, it appears that there has been steady improvement in this regard. Ogbalu championed the course of textbook writing in Igbo. Ubesie and others followed suit including Nwadike, Ezike Ojiaku, Onyekowu, and others. It is also observed that the use of ICT (Information and Communication Technology) in the teaching and learning of Igbo language is still backwards compared with that of English language. The reason is not far-fetched. Our children are gradually loosing grip of their language, because Igbo plays and dramas that could have brought their lost hopes back are not in place. For instance, both Yoruba and Hausa languages have slots in the DSTV (Digital Satelite Television) where their languages are permanently used in home movies, whereas the Igbos has no slot except in English language. This made our children to loose sight of the Igbo proverbs and idioms.

If the Igbos can take up the challenge of showcasing their films in their own language, our children's interest will be reviewed. Teachers of Igbo language should use these Igbo home movies to draw their lessons home and also encourage the pupils to watch them instead of watching only foreign films which does not help them to build up their Igbo vocabulary. The government and well placed Igbo scholars can also sponsor the production of Igbo movies thereby popularizing it, N'ihi na ebe onye bi ka o na-awachi (Cherish and preserve your inheritance).

\section{Teacher's Preparedness}

Writing on the preparedness of teachers, Macgrats in Umo (1996) said "that the need for competency on the part of language teachers is of importance” (p. 19). He stressed that no programme of instruction at any level could be successful when teachers were not sufficiently proficient in language. Still on teachers preparedness, Arogurdade (1991) noted that:

We should be quit to realize that pupils' use of language for learning are strongly influenced by their teachers' tongue, because the later prescribe rules for the former as learners. Most of the teachers we have in the field presently really do not have a good grasp of their mother-tongue and this is amply evidenced by their inability to fluently discuss, read, or write in the language. (p. 175) 
Therefore, unless teachers whom themselves understand these languages of the immaculate environment are trained, imparting the best knowledge into learners may be impeded, which will lead to loss of identity. Both governmental and non-governmental agencies should be involved in this training process. Igbo student teachers should be motivated and encourage. Bursaries, awards and scholarships should be instituted to encourage learning of Igbo language in higher institutions. In universities, chairs should be instituted for Igbo professors by donor agencies. This will help attract the best brains amidst indigent students into the area.

\section{Nature of Igbo Language}

The nature of Igbo language also constitutes problems to Igbo scholars. This is because Igbo language is vast and has three major areas namely the language, literature, and culture. This is why Okeke (2001) confirmed that the scheme of work drawn from Igbo language curriculum has never been finished in any particular year due to its nature. Furthermore, Igbo language is marked with complex system of tonations in distinguishing meanings and grammatical and phonological relationships in a wild range of dialectical variations which creates problems both to foreign learners who study Igbo as L2 (second language) and to the owners of the language who study it as L1 (first language).

On the issue of diacritic marks the adoption of African orthography in 1929 was guided by at least three objective considerations namely: (1) to represent the essential sound of language by separate letters; (2) to get rid of diacritics as far as possible; and (3) to supply spelling as far as possible.

The Onwu committee on the promotion of language and culture adopted principle "a \& c" and rejected "b", which aim at avoiding the use of diacritics. The Onwu committee recommended the use of diacritics and once a person does not put them where they are supposed, then the problem arises because the word automatically looses their meaning (see Examples (1)).

Example (1) Egbe and egbe

Oku and oku

Ukwu and ukwu

Onu and onu

Oke and oke

Akwa and akwa

Akpa and akpa

Isi and isi etc..

The issue here is that without diacritic marks, these words would be meaningless and create problems which invariably affect the way Igbo man sees the language, which makes him to loose identity.

\section{Government Policy}

In our country today, emphasis is being laid on learning the three main Nigeria languages as a means of preserving their people's culture. With this in mind, the FRN (Federal Government of Nigeria) (1981) came up with the national language policy, which stated that:

In addition to appreciating the importance of the educational process and as a means of preserving the peoples' culture, the government considers it to be in the interest of national unity that each child should be encouraged to learn 
one of the three major languages other than his own mother tongue. In this connection, the government considers the three major languages in Nigeria to be Hausa, Ibo, and Yoruba. (p. 8)

This is to foster national unity and for intertribal communication among Nigerians. The policy also states that "Government will see that the medium of instruction in the primary school is initially the mother tongue or the language of the immediate community an at later stage, English” (FRN, 1981, p. 13), which is generally understood to mean that English should be used from primary four.

The problem with government policy is that government does not supervise or see the full implementation of the said policy. Many policies have come and gone, and this made the teachers to perceive the policy as mere statement of the government policy which is never actualized in its reality.

\section{Orthography Controversy}

Igbo language studies commenced with the introduction of Igbo orthography produced by Lepsius in 1854 (Oraka, 1983). In 1929, the “Africa” orthography referred to as “Adam ward”, R.C.M (Roman Catholic Mission) came to replace the African orthography. As a result of this, prolonged and vigorous controversy ensured. The controversy slowed down the rate of growth and development of Igbo as a literary language. Many writers on the subject lost interest. For instance, Oraka (1983) reported that Schon became disgusted and gave up the idea of developing the Igbo orthography. This orthography controversy was between the Roman Catholic Mission and the giant mission, and it came when people were trying to show interest on the study of Igbo language. The problems seem compounded as books have been written with different orthographies yet, these books were read by students of Igbo language, especially, in the churches. These students naturally had problem in reconciling the different orthographies.

The controversy surrounding Igbo orthography lingered till 1961 when Onwu orthography committee, which was set up by the government of eastern rejoin, came up with new orthography which consisted of 36 letters. It also consisted of eight vowels and 28 consonants. Emenanjo (1985) observed that the committee was made up of untrained linguists who were ignorant of what orthography meant, and because of this, they failed to provide the following spellings of distinctive features like vowel assimilation, consonants elisions etc.. He pointed out that the committee also failed to make clearly the writing system of loan words, punctuation, and dialect form to be used in literary writing. He claimed the fact that Onwu orthography failed to recommend such things that the problem arising from the above oversight are still with the study of Igbo language. This standardization was formed by the SPILC (Society of Promoting Igbo Language and Culture) in 1973 so as to get Igbo people involved in using Igbo in discourse and writing to have a standard. They forced all the writing fashion to adopt. This was sent to all examination bodies, institutions, and churches (Emenanjo, 1978). The recommendations have been published in two volumes. Volume one deals with orthography, spelling rules, dialects, loan words, tone, and technical vocabulary. On the orthography, they unanimously agreed to adopt Onwu orthography, but only to re-arrange the 36 letters in alphabetical order. Volume two of the standardization deals with mathematical and scientific terms, numeration in Igbo, names of animals and plants. (SPILC, 1974, Vol. I \& II) Stressing the improtnace of standard Igbo, Emenanjo (1980) in his book titled, (SPILC) asserted that we ought to assimilate standard Igbo and put them into practice so that our knowledge on standard Igbo for effective communication should not be a mere waste. 
Nevertheless, the Onwu orthography despite its short comings, formed the basis for the central Igbo language as we have toady. There appear to be no more controversy about the orthography, but the alphabetical arrangement seems not to enter deep into the minds of those who are already used to the old orthography. Teachers must enforce this orthography and make it flow naturally in pupils' every day expression. Personally, these authors do not even believe that it is proper to use English alphabets to place the Igbo alphabets in alphabetical order. The sound when the new placement is read is awful.

On the other hand, on the effect of orthography, Nwadike (2008) lamented that it has done the following harm: (1) It limits the development of the literary language and production of literature; (2) publishers refuse to publish in Igbo; (3) worse than that, Messrs Longmans and Green published Igbo books in the new orthography but were unable to find enough buyers because of the divided loyalty to the orthographies; (4) it scared would-be Igbo authors, many of whom turned to English; and (5) the dispute created consciousness among the adherents of the protestants and the catholic church.

We thank God that the rift between the protestants and Catholic Church on choice of orthography has diminished to the barest minimum. The Catholic church recently commissioned the translation of English bible to Igbo. This recent development appeared to fall in line already existing bible translations. Therefore, religious agents have a lot of roles to play in popularizing current standard Igbo language.

\section{Nkiruka}

A practical evidence that exemplifies the dictum Nkiruka.

The author in her doctoral degree dissertation carried out a research on the effect of games on the achievement of and interest of junior secondary school students in Igbo. It is pertinent at this juncture to highlight the summary of the study to prove that there is hope and the future of Igbo language is not bleak hence "Nkiruka".

The achievement and interest of students in Igbo language and grammar, in particular, has been on the decline. The major reason attributed to this poor performance is poor method of teaching.

The purpose of this was to determine the effect games as a teaching strategy on the achievement and interest of students in Igbo grammar. Six researches questions were generated to guide the study. It was hypothesized that: (1) the game strategy will not have significant effect on the achievement and interest of students in Igbo; (2) gender will not be a significant $(p<0.05)$ factor on student's achievement and interest in Igbo; (3) location will not be a significant $(p<0.05)$ faster on student's achievement and interest in Igbo; (4) there will be not significant interaction effect of method and gender on students' achievement and interest; and (5) there will be not significant effect of method and location on the achievement and interest of students in Igbo.

After review of related literature, quasi-experimental study of non-equivalent control group design involving eight intact classes (four males and females) were used for the study. 197 JSSII (Junior Secondary School 11) students constitute the sample for the study. The schools were drawn from Nsukka education zone of Enugu state. The sampled schools were randomly assigned by balloting to the treatment group and control conditions. Regular Igbo teachers who were earlier trained by the researcher taught the students. Identified extraneous variables were controlled and all the groups were pre and post-tested.

Data collection was done using IGAT (Igbo Grammar Achievement Test) and ILII (Igbo language Interest Inventory) developed by the researcher. An internal consistency reliability of 0.82 using Kuder Richardson 
formula 20 was computed for IGAT, while an internal consistency of 0.63 using Cronbach Alpha formula was calculated for ILII. The data generated from the study was analysed using means, standard deviation, and $2 \times 2 \times 2$ analysis of covariance. The treatment lasted for four weeks. In the experimental condition, games, like vowel harmony games, were used while conventional lecture method was used for the control setting.

The result showed that: (1) There was no significant effect of game strategy on students' achievement in Igbo grammar; (2) there was a significant effect of game strategy on students' in Igbo; (3) gender was a significant factor on the achievement and interest of students in Igbo; (4) location had a significant effect on both the achievement and interest of students in Igbo; and (5) the combined effects of the variables method, gender and location had an influence on both the achievement and interest of students in Igbo but when a pair wise comparison was made on the independent measures, there was significant effect on interest.

The education implications of the findings were also discussed. The limitations of the study were also exposed, while some recommendations were made which include among others that seminar and workshops should be organized by various organs of government including the researchers, on the importance of innovative strategies like games in teaching and learning process, especially, in the areas of language education.

\section{Conclusion}

Language is man's identity. By implication Igbo language is Igbo man’s identity. The paper has raised some issues on the difficulties encountered in the teaching and learning of Igbo language which is, as matter of fact, is the major reason why its identity is lost. Nkiruka is a name, Tabugbo is also a name, they all buttress to hope for better future. We should not fold our hands and allow Igbo language to go into extinction. Something serious must be done to salvage the image of the language in order to re-position it for its proper identity.

In the case of negative attitude, government should try and motivate learners of Igbo language. Igbo teachers should also be encouraged. Parents and educated elites should change their negative attitude towards the language. They should feel free to discuss with Igbo language like their counterparts in Yourba and Hausa. We should be proud of our language because that is our cultural identify "nkemjika".

\section{Recommendations}

In solving dialectical problems, the Igbo linguist should try and document all the slight phonological and word differences existing in the dialects and absorb them in central Igbo. The Igbo linguist can also identify the teaching of standard Igbo in schools occupied by particular dialects.

The teaching of Igbo should be made compulsory at all levels of our educational institutions. Department of Linguistics and other Nigerian languages in our Universities should encourage interdisciplinary approaches with departments such as French, English, German, Russian etc. in the area of translation. These approaches will create great awareness of Igbo language, Culture and Traditions which, in turn, will showcase Igbo scholars and non-Igbo scholars for proper identity. This is because a language whose literature is not read by other people cannot grow (Ohaegbu, 2010).

In the area of tone, Igbo language being a tonal language should be taught like Yoruba language. By this, some Igbo words that have the same spellings can only be taught putting "tone marks" on the vowels of their words (see Examples (2)-(3)). 


$\begin{aligned} \text { Example (2) làkwá } & \text { egg } \\ \text { ákwà } & \text { cloth } \\ \text { àkwà } & \text { bed/bridge } \\ \text { ákwá } & \text { cry }\end{aligned}$

The teacher teaches the tone marks as: (1) High tone “””; (2) Low tone “””; and (3) Down step tone “_”. $\begin{aligned} \text { Example (3) Óké } & \text { rate } \\ \text { Ókè } & \text { boundary } \\ \text { Òkè } & \text { share } \\ \text { Óké } & \text { male }\end{aligned}$

Research findings also confirmed what Bamgbose (1990) said that: Although several schools supposedly operate on mother tongue medium policy but finds that there are hardly any text book. The implication of this inadequacy of teaching support materials is that the policy is not fully being implemented. It is suggested that Igbo specialists should be involved in text book writing and curriculum planning for Igbo language.

Finally, the Igbo language as an identity for Igbo man should not be taken as a derogatory rather it should be embraced with pour whole heart because "Nkem bu Nkem, Ma Nke anyi bu Nke anyi (mine is mine, ours is ours)" Igbo Kwenu. We should know that appropriate use of language maintains a uniform identity. Igbo language has lost its identity and we want it back. Nkiruka bu Eziaha (greater future is a good name).

\section{References}

Afigbo, A. E. (1975). The place of Igbo language in schools. In F. C. Ogbalu, \& E. N. Emenanjo (Eds.), Igbo language and culture. Ibadan: Oxford University Press.

Arogundade, O. B. (1991). The issue of implementation of mother tongue education in Nigeria primary schools: Problems and prospects. In T. O. Ehiametalor, W. O. Olu-Aderounmu, S. O. Olaitan, \& O. J. Afe (Eds.), Teaching and learning in Nigeria languages. Ikere-ekiti: Nigeria Education Asssociation.

Baldeh, F. (1990). Better English language learning and teaching. Nsukka: Fulladu Publishing Company.

Bamgbose, A. (1990). Mother tongue as a medium of instruction in primary school is okay. Paper read at the 11th Conference of the Linguistics Association of Nigeria, University of Calabar.

Bucholtz, M. (1999). Why be normal? Language and identity practices in a community nerd girls. Language in Society, 28(2), 203-225.

Chukwukere, F. N. (2006). Meeting the challenges of the identify, gender and other related issues in the 21st century Igbo literary writing. Journal of Igbo Studies, 1(1), 65-72.

Emenanjo, N. (1975). Central Igbo: An objective appraisal. Ibadan: Oxford University Press

Emenanjo, N. (1978). Element of modern Igbo grammar. Ibadan: Oxford University Press.

Emenanjo, N. (1980). Language modernization from the grassroots: The case of Igbo. Paper read at SPILC Seminar, Nsukka.

Emenanjo, N. (1985). Nigerian language policy: Perspective and prospective. Journal of Linguistic Association of Nigeria, 3 , $123-124$.

Fafunwa, B. A. (1975). Education in mother-tongue: A Nigerian experiment. The six year (Yoruba Medium) primary education project at university of Ife. West African Journal of Education, 19, 231-218.

Fafunwa, B. A. (1985). Education in mother tongue. The Ife primary education research project 1970-1978. Ibadan: University Press.

Federal Republic of Nigeria. (1981). National policy on education. Lagos: Federal Ministry of Information.

Ikekeonwu, C. (1985) Aspect of Igbo dialectology: A comparative phonological study of Onitsha and central Igbo dialects. Journal of West African Linguistics, 15(3), 113-127.

Ikekeonwu, C. I. (1986). A lexico-phonotactic study of the northern Igbo dialects (Ph.D. Thesis, University of Nigeria, Nsukka). 
Nwadike, I. U. (2008). Igbo language and culture. Whither bound? (Chief (Dr.) F.C. Ogbalu memorial lecture $1 \times 3$ delivered at Nnamdi Azikwe University, Awka).

Nwadike, I. U. (2008). Igbo studies: From the plantation of west indices to the forest land of west Africa 1766-2008. (An inaugural lecture of the University of Nigeria, Delivered on June 12, 2008).

Nwokedi, R. E. (1984). Language problems in teaching and learning in Nigerian physics. Nigerian Language Teacher, 6(1), 8-16.

Nwozuzu, G. I. (2008). Dialects of the Igbo language. Nsukka: University of Nigeria Press.

Ogbalu, F. C. (1974). Standard Igbo: Part to its development. Onitsha: University of Publishing Company Ltd..

Ogbalu, F.C. (1975). Igbo language and culture. Ibadan: Oxford University Press.

Ohaegbu, A. U. (2010). Language and issues in Igbo language development. A key note address delivered on the occasion of The 5th Annual Conference of Igbo Studies Association (ISA).

Okeke, L. E. (2001). Utilization of instructional material in secondary school language teaching. International Journal of Studies in Humanities (IJOSH) 1x2(2), 119-132.

Okobiah, O. (1990). Teaching method and strategies. In E. J. Maduewesi (Ed.), General methodology in primary schools in Nsukka. Nsukka, Nigeria: Africana Fep Publishers Ltd..

Olagoke, D. O. (1979). The mother tongue and ESL in Nigeria. In Ubahakwe, (Ed.), The teaching of English language studies. Ibadan: University Publishers.

Oluikpe, B. O. (1979). Igbo transformational syntax: The Ngwa dialect example. Onitsha: African Educational Publishers.

Onyekaonwu, G. (1956). Uwa ntoo (What a hopeless world). Onitsha: Africa Fep.

Oraka, N. (1983). The foundations of Igbo studies. Onitsha: University Publishing Company.

Spolsky, B. (1999). Secondary language learning. In J. Fishman (Ed.), Handbook of language and ethnic identity (pp. 181-192). New York: Oxford University Press.

Taiwo, C. C. (1980). The Nigerian education system, past, present and future. Ibadan: University Thomas Nelson.

Ubahakwe, E. (1977a). Igbo language studies. A Re-assessment of Secondary School Curriculum Odenigbo, 181(11), 98.

Ubahakwe, E. (1977b). Nigerian language in modern education. Ibadan: University Press.

Ubahakwe, E. (1979). The teaching of English studies readings for colleges and universities. Ibadan: University Press.

Umo, U. C. (1996). The implementation of national language policy at the junior primary school in Nsukka (Unpublished M.Ed thesis, University of Nigeria, Nsukka).

Umo, U. C. (2001). Effects of games on the achievement and interest of junior secondary school students in Igbo grammar (Unpublished Ph.D thesis, University of Nigeria, Nsukka).

WAEC (The West Africa Examinations Council). (1993-1997). Chief examinees report on Igbo language. May/June. Lagos: Federal Ministry of Education.

Ward, I. C. (1941). Igbo dialects and the development of a common language. Cambridge: Heffer \& Sons Ltd.. 